\title{
ANALYSIS OF THE INFLUENCE OF INTEREST RATE, EXCHANGE VALUE, WORLD GOLD PRICES, DOW JONES INDEX, AEX INDEX, DAX INDEX, AND SHANGHAI INDEX ON LQ45 INDEX IN INDONESIA STOCK EXCHANGE 2012 - 2018
}

\author{
Oleh: \\ Andini Nurwulandari ${ }^{1}$ \\ Hasanudin $^{2}$ \\ Ari Jatmiko Setiyo Budi ${ }^{3}$ \\ Program Studi Manajemen \\ Sekolah Pascasarjana Universitas Nasional Jakarta \\ Email: \\ andinmanajemen@gmail.com \\ hasanudinsadikin910@gmail.com \\ arrays79@yahoo.com
}

\begin{abstract}
This research aims to find out the influence of interest rate, exchange rate, world gold price, Dow Jones Index, AEX Index, DAX Index, and Shanghai Index on the LQ45 Index at the Indonesia Stock Exchange from 2012 through 2018 using the ARCH/GARCH model as the method of analysis. The result of the test shows that the exchange rate had a significant negative influence, Dow Jones Index, AEX Index, and DAX Index had a significant positive influence on the LQ45 index, while the interest rate and world gold price had a non-significant negative influence and the Shanghai Index had a non-significant positive influence on the LQ45 index.
\end{abstract}

Keyword: LQ45 Index, Interest Rate, Exchange Rate, World Gold Price, Dow Jones Index, AEX Index, DAX Index, Shanghai Index

\section{A. INTRODUCTION}

Investment is a factor that is judged to have an impact on the economy of a country. Business leaders have taken a keen interest in investment activities. Investment is an activity in delaying current consumption and is diverted to purchase investment instruments in hopes of getting a chance to make more future consumption. There are two kinds of investment instruments covering real investment and financial investments. Real investment is a type of investment in real assets such as land, machine, factory, building, and so forth, while financial investment is an investment in a contract letter on a piece of paper or an electronic document such as obligation and stock. One option of investing can be made through the stock market. Investors' expectations in investing in stocks in addition 
to becoming the owners of a company with certain ownership proportionate, the shares invested are expected to provide a predetermined return or return rate.

Speaking about the current capital market cannot be separated from what is called the stock price index. In electronic media as well as in other mass media, every day always reports information related to movements and changes in the Jakarta Composite Index, better known as the latest JCI that occurred. One of the stock price indexes on the Indonesia Stock Exchange is the LQ45 stock price index. The LQ45 stock price index generally consists of stocks that are considered the most liquid and have the largest market capitalization, the movement of this index is very similar to the JCI. The stocks that are incorporated in LQ45 represent around $65 \%$ of the capitalization of the IDX.

At a macro level, economic problems affect share prices (Lai et al., 2017), (Wahyudi et al., 2017) because economic problems are related to policies taken by the government to spur and control the pace of the country's economy so that it can run in a balanced manner, in line with the instruments of economic power that are owned and safe and can avoid obstacles that can be disturbing the balance of the country's economy. One of the policies provided by the government during economic shocks such as inflation is to set the reference interest rate. Highinterest rates reduce the present value of future cash flows so that the attractiveness of investment opportunities decreases because these real interest rates are a key determinant of business investment spending.

The exchange rate in this study is the exchange rate (exchange rate) of Rupiah against the value of the US Dollar (USD) because the value of the United States Dollar is still the main reference for world currencies and the main reference for currency exchange in the world. A mature United States financial market has invested USD more fertile until now the Dollar (USD) is still the standard exchange rate around the world. Foreign currency and other means of payment are required to conduct or finance international financial economic transactions (export-import). The higher the growth rate (relative to other countries), the greater the possibility for imports, which means the greater the demand for foreign exchange.

Apart from factors originating from within the country, some factors originate from abroad that affect the stock price index, namely fluctuations in the world gold price. Gold is one of the most popular commodities in the investment world. The increase in the price of gold is considered to be able to pressure investors to choose gold as an investment compared to the capital market. Because with a relatively lower risk, gold can provide high returns. When many investors shift their investment portfolios to gold investment instruments, this will result in a decline in investment activities in the capital market by investors who will result in a decrease in stock price index returns. This is supported by (Chabachib \& Witjaksono, 2011), where one of the investments that tend to be risk-free is gold.

The United States, the Netherlands, Germany, and China have a major influence on the Indonesian economy. China's influence is mostly through trade channels and commodity prices where Indonesia views China as the main export destination for goods, including commodities. Meanwhile, American influence is 
the most through the financial channel because transactions and investment funds that enter Indonesia are denominated in US dollars. For the European region, the Netherlands and Germany are the main export destinations from Indonesia, and the Netherlands also makes the highest foreign investment in Indonesia in the European region, and Germany is the lead of the European economy.

One of the factors of economic development can be illustrated through the performance of the capital market, which is illustrated in the graph in Graph 1 below.

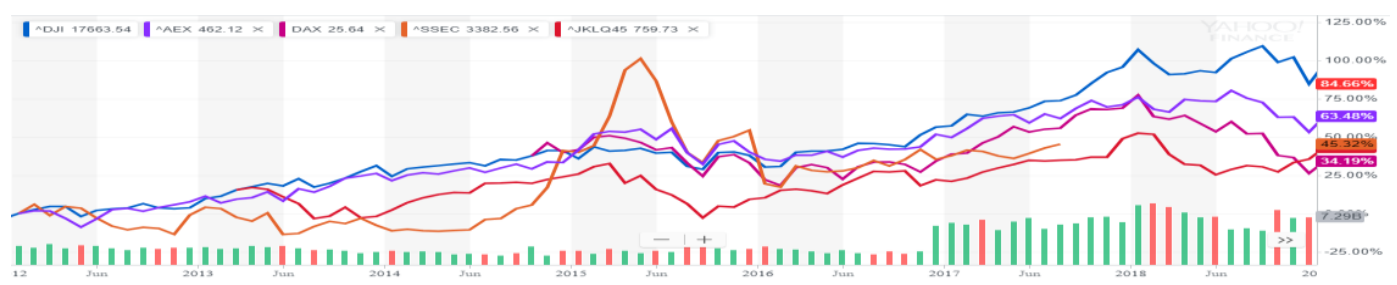

Sources: www.finance.yahoo.com

\section{Graph 1 \\ Dow Jones Index (DJIA), AEX Index, Shanghai DAX Index (SSEC), and LQ45 Index 2012 - 2018}

In Graph 1, it can be seen that the performance of the Indonesian Capital Market tends to follow the performance of global exchanges, especially the Dow Jones Index, AEX Index, DAX Index, and the Shanghai Index. This can be seen when the global stock exchange experiences a sluggishness, the Indonesian stock index also decreases, and vice versa, when the global stock market increases, the Indonesian stock index also increases. Stock investors around the world respond to various events around the world in the form of selling or buying shares. If there is an event that is considered to increase investment risk in the future, investors will tend to sell shares to avoid potential losses in the future. Likewise, if there is an event that is considered to increase potential profit, investors will respond by purchasing shares.

The economies of developed countries influence the current global economy. The United States, China, and Europe are countries that have a significant influence on the global economy. The Netherlands is one of the countries that is part of the European Union also has a role in influencing the global economy and even Indonesia. The Netherlands is one of the main export destinations for products from Indonesia in the European region, the Netherlands is also the largest investor in foreign investment (PMA) in Indonesia compared to other countries in the European region. The Netherlands and Indonesia also have long historical ties, it cannot be denied that the economic system in the Netherlands has an impact on the economic system in Indonesia.

As the leader of the European economy, of course, the German economy has influenced the global economy. The German economy, which is reflected in the DAX Index, affects the global economy, especially Indonesia, this is evidenced by the results of research on the DAX Index supporting the theory above, conducted by (Fuadi, 2013), (Tarigan, 2015), (Sakinah, 2016), (Sawitri \& 
Astuty, 2018). However, research with different results has been conducted by (Desfiandi1 et al., 2017), (Aditya et al., 2018) which states that the DAX stock index variable has no significant effect on the JCI stock index. Different previous research results show a research gap regarding the effect of interest rates, exchange rates, world gold prices, the Dow Jones index, AEX index, DAX index, and the Shanghai index on the LQ45 index.

\section{B. LITERATURE REVIEW}

\section{LQ45 Index}

The Indonesian capital market is still classified as a thin market, namely the capital market where most of the securities are less actively traded. The JCI, which includes all listed shares (most of which are less actively traded), is considered an inaccurate indicator of capital market activity. Therefore, on February 24, 1997, an alternative index was introduced, namely the LQ45 index (Liquid 45).

\section{Interest Rate}

The interest rate or better known as the BI Rate is a policy interest rate that reflects the monetary policy stance or stance set by Bank Indonesia and announced to the public (Bank Indonesia, 2018). The BI Rate is announced by the Board of Governors of Bank Indonesia every month The operational targets for monetary policy can be seen in developments in the interest rates on the Overnight Interbank Money Market (PUAB O/N).

\section{Exchange rate}

The exchange rate is the price of one currency which is stated according to other currencies. From these two definitions, it can be concluded that the exchange rate is an exchange rate that indicates the number of units of a particular currency that can be exchanged for other currencies.

\section{World Gold Price}

Since 1968, the London gold market standard has been used as the benchmark for world gold prices. The system used is known as The London Bullion Market Association (LBMA). The London Bullion Market Association is the main body that controls and determines the gold price standard around the world. The process of determining the price is carried out twice in one day, namely at 10.30 (Gold A.M) and 15.00 (Gold P.M).

\section{Dow Jones Index}

The DJIA Index was founded by Charles Dow, editor of the daily Wall Street Journal and founder of Dow Jones and Company (www.us.indices.com). This index is created to represent the stock performance of large and leading companies in the United States except for transportation and utility companies. 
The DJIA Index contains the 30 (thirty) largest companies in the United States that have gone public and is the oldest stock market index in the United States that is still running.

\section{AEX Index}

The Amsterdam Exchange Index (AEX) or popularly known as the AEX Index is a stock market index consisting of Dutch companies traded on Euronext Amsterdam which was known in ancient times as the Amsterdam Stock Exchange. This index was officially inaugurated in 1983 under the name European Options Exchange, which consists of the 25 largest companies traded on this exchange, and every March 1st of each year, the composition of this index will be updated.

\section{DAX Index}

Deutscher Aktien Index (DAX) - the German stock index is an index of the stock market in Germany, which contains 30 major companies in Germany that trade on the Frankfurt Stock Exchange. The DAX is a capitalization considered like France's CAC 40 and measures the performance of the 30 largest and most publicly traded German companies, where it represents $80 \%$ of the total German market capitalization. Requirements for companies to enter DAX 30 must be listed on the Prime Standards on the Frankfurt Stock Exchange, with a minimum of $10 \%$ of the shares of the listed companies held by the public, as well as several other criteria to be considered part of this index.

\section{Shanghai Index}

The Shanghai Stock Exchange (SSE) is the largest in the People's Republic of China. SSE is located in the city of Shanghai, PRC. The Shanghai Stock Exchange was established on November 26, 1990, and started operations on December 19 that year. The stock exchange is a non-profit organization managed by the China Securities Regulatory Commission (CSRC).

\section{RESEARCH METHOD}

The population in this study is monthly data from the LQ45 Index on the Indonesia Stock Exchange, Interest Rates from the BI Rate, and BI 7-day (Reverse) Repo Rate, Exchange Rates from JISDOR which are announced on page www.bi.go, id, World Gold Prices. on the www.lbma.org.uk page, the Dow Jones Index on the official website of the Ney York Stock Exchange, the AEX Index on the official website of the Amsterdam Stock Exchange (a member of the Euronext group), the DAX Index on the official website website) Börse Frankfurt (Frankfurt Stock Exchange) and the Shanghai Index from the official website (official website) of the Shanghai Stock Exchange and the pages www.finance.yahoo.com. The sample used is saturated. So that all members of the population are used in this study. Research data analysis was carried out through Eviews software with the Autoregressive Conditional Heteroskedasticity (ARCH) 
Model/Generalized Autoregressive Conditional Heteroskedasticity (GARCH) model. Historical data uses monthly data for the months of January 2012December 2018.

\section{RESULTS AND DISCUSSION}

\section{Results}

\section{Data Behavior Test (Data Stationarity Test):}

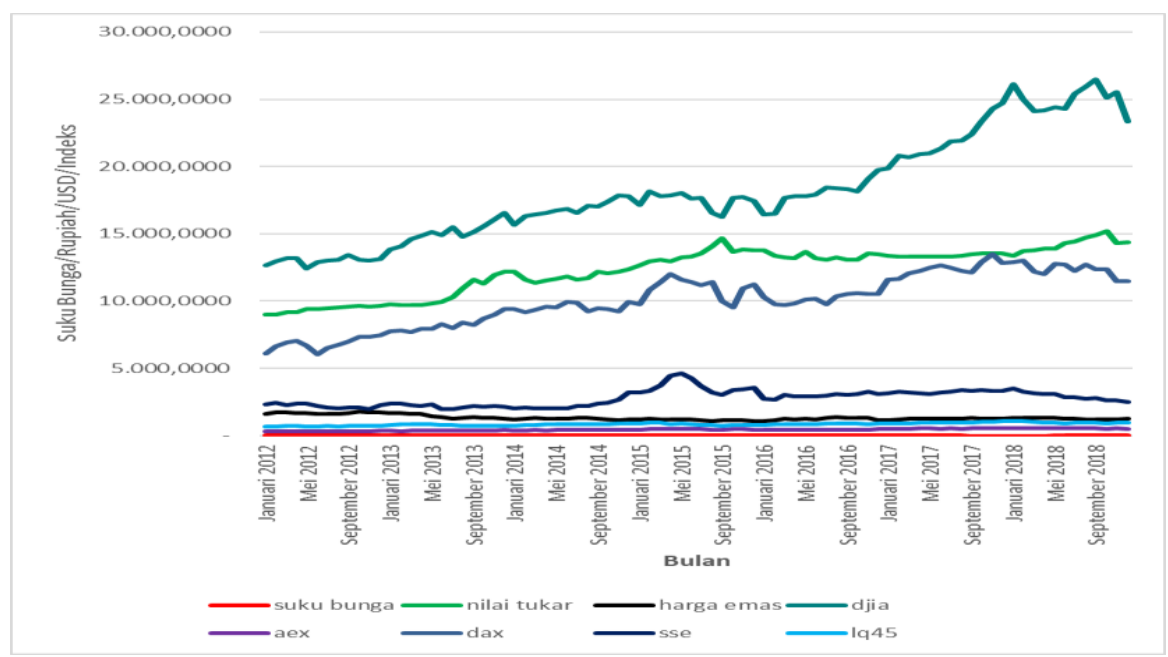

\section{Graph 2}

\section{Research Variable Graph}

In Graph 2, it can be seen through graphic observation, the research variable data is not stationary. However, the assessment of the data behavior test through graphics data observation is very dependent on the objectivity of the data observation, so the test is continued with formal testing using the Unit Root Test method. From testing the Unit Root Test method, this differentiator produces the ADF value of the eight research variables that are negative smaller than the MacKinnon table so that the eight research variables can be said to be stationary. The next test uses the Correlogram that is test results illustrate that the Correlogram (ACF and PACF) graphs of the eight research variables in the first lag are within the Bartlett line, which indicates that the data of the eight research variables are stationary.

\section{ARCH/GARCH Model}

\section{Model Selection}

Estimating parameters by reducing or adding the order $p$ and $q$ iteratively with the Marquardt Algorithm. The order chosen is only up to order 2 because the presumed parameter is less significant when the order is used more than 2. For 
this study, the ARCH (1), GARCH $(1,1)$, GARCH $(1,2)$, GARCH $(2,1)$, and GARCH $(2,2)$. From the results of processing Eviews 10, the following equation is produced:

$\operatorname{ARCH}(1): \sigma^{2}=684,7479+0,9435 \varepsilon_{t-1}^{2}-0,6408 \varepsilon_{t-1}^{2} \varepsilon_{t}$

$\operatorname{GARCH}(1,1): \sigma^{2}=1297,993+0,9029 \varepsilon_{t-1}^{2^{t-1}}-0,7743 \varepsilon_{t-1}^{2} \varepsilon_{t}-0,2361 \sigma_{t-1}^{2}$

$\operatorname{GARCH}(1,2): \sigma^{2}=1465,118+0,8475 \varepsilon_{t-1}^{2}-0,6484 \varepsilon_{t-1}^{2} \varepsilon_{t}-0,2099 \sigma_{t-1}^{2}-0,1230 \sigma_{t-2}^{2}$

$\operatorname{GARCH}(2,1): \sigma^{2}=672,2255+-0.5975 \varepsilon_{t-1}^{2}-0.3978 \varepsilon_{t-1}^{2} \varepsilon_{t}-0,3827 \varepsilon_{t-2}^{2}+0.553 \sigma_{t-1}^{t-2}$

$\operatorname{GARCH}(2,2): \sigma^{2}=710,1859+0,6771 \varepsilon_{t-1}^{2}-0,4262 \varepsilon_{t-1}^{2} \varepsilon_{t}-0,3845 \varepsilon_{t-2}^{2}+0,4519 \sigma_{t-1}^{2}-0,0002 \sigma_{t-2}^{2}$

From the equation model above, it can be found that the GARCH Model $(1,2)$ is the best because it has the largest R2 coefficient value, namely, 0.809929, scattered Adjusted R2 is 0.792422 and the largest Log Likelihood is -430.9222 and has the AIC value. the smallest is 10.50577 and the smallest SC is 10.82197. It can be seen in the following table:

Table 1

Best Model Selection Results

\begin{tabular}{cccccc}
\hline Model & $\begin{array}{c}\mathbf{R}^{\mathbf{2}} \\
\mathbf{( R -} \\
\text { squared) }\end{array}$ & $\begin{array}{c}\text { Adjusted R } \\
\text { (Adjusted R- } \\
\text { squared) }\end{array}$ & $\begin{array}{c}\text { Log- } \\
\text { Likelihood }\end{array}$ & $\begin{array}{c}\text { AIC } \\
\text { (Akaike Info } \\
\text { Criterion) }\end{array}$ & $\begin{array}{c}\text { SC } \\
\text { Schwarz } \\
\text { Info } \\
\text { Criterion }\end{array}$ \\
\hline ARCH (1) & 0,766391 & 0,744875 & $-430,4438$ & 10,51057 & 10,82889 \\
GARCH (1,1) & 0,805581 & 0,787674 & $-429,2798$ & 10,50666 & 10,85392 \\
GARCH (1,2) & $\mathbf{0 , 8 0 9 9 2 9}$ & $\mathbf{0 , 7 9 2 4 2 2}$ & $\mathbf{- 4 3 0 , 9 2 2 2}$ & $\mathbf{1 0 , 5 0 5 7 7}$ & $\mathbf{1 0 , 8 2 1 9 7}$ \\
GARCH (2,1) & 0,784327 & 0,764462 & $-429,2779$ & 10,53043 & 10,90662 \\
GARCH (2,2) & 0,785021 & 0,765220 & $-429,3170$ & 10,55517 & 10,96030 \\
\hline
\end{tabular}

Model Accuracy Testing

Table 2

Model Accuracy Testing Results

\begin{tabular}{lcrl}
\hline \multicolumn{1}{c}{ MODEL } & \multicolumn{1}{c}{ MAE } & MAPE & RMSE \\
\hline ARCH $(1)$ & 38,95642 & 4,505346 & 50,54614 \\
GARCH $(1,1)$ & 37,81519 & 4,432087 & 46,11187 \\
GARCH (1,2) & $\mathbf{3 7 , 6 3 9 6 3}$ & $\mathbf{4 , 4 2 8 2 1 9}$ & $\mathbf{4 5 , 5 9 3 3 8}$ \\
GARCH $(2,1)$ & 39,16174 & 4,542244 & 48,56703 \\
GARCH $(2,2)$ & 39,17267 & 4,544333 & 48,48882 \\
\hline
\end{tabular}

Based on table 2 it can be explained that the GARCH Model $(1,2)$ is the most accurate because it has the smallest MAE value, namely 37.63963, the smallest MAPE value is 4.428219 and the smallest RMSE value is 45.59338. From the results of Eviews 10 data processing, it is found that the Trace Statistic value is 311.4528 greater than the Critical Value, namely 159.5297 and so is the Max-Eigen Statistics value which is 93.64747 greater than the Critical Value which is 52.36261 thus, in the long run, there is cointegration in the equation model. 


\section{Discussion}

Based on the results of the analysis, it is found that the interest rate has a negative effect on the LQ45 Index on the Indonesia Stock Exchange 2012 - 2018 amounting to 548.7896 with a significance level greater than 0.05 , it is concluded that the effect is not significant. From the analysis results, it can be seen that the effect of the interest rate is not by the hypothesis where the effect is not significant. This is because during the observation period the Interest Rate (BI Rate) did not experience significant fluctuations. Research that supports these results is research conducted by (Tjandrasa \& Sutjiati, 2016), (Haider, 2018).

\section{$H_{1}$ : Interest rates have a negative effect on the LQ45 Index on the Indonesia Stock Exchange 2012 - 2018.}

From the analysis results, it can be seen that the effect of the Exchange Rate is following the hypothesis where the effect is significant. This shows that in the observation period investors pay attention to interest rates as a variable in their investment evaluation. This also illustrates that most of the investors in the Indonesia Stock Exchange are foreign investors who see that the decline in the value of the rupiah against the US Dollar (devaluation) can reduce the value of their investment assets in Indonesia. The fluctuation of the Rupiah Exchange Rate is a reflection of domestic economic conditions and as an indicator of investors investing in the Indonesia Stock Exchange. Research that supports these results is research conducted (Purnamawati \& Werastuti, 2013) (Ilmi, 2017), (Wahyudi et al., 2017), (Widyasa \& Worokinasih, 2018), (Robiyanto, 2018).

\section{$\mathrm{H}_{2}$ : Exchange Rate has a negative effect on the LQ45 Index on the Indonesia Stock Exchange 2012 - 2018.}

Based on the results of the analysis, it is found that the World Gold Price has a negative effect on the LQ45 Index on the Indonesia Stock Exchange 2012 2018 amounting to 0.040906 with a significance level greater than 0.05 , it is concluded that the effect is not significant. From the analysis results, it can be seen that the effect of the World Gold Price is not in accordance with the hypothesis where the effect is not significant. This is because, during the research period, stocks became the most promising instrument for-profits, considering that the Fed raised interest rates several times, prompting an increase in stock prices, especially the banking sector, which in turn could boost the index increase. Research that supports these results is research conducted by (Syarif \& Asandimitra, 2015), (Surbakti et al., 2016), (Husnul et al., 2017), (Yulianti \& Purwohandoko, 2019).

\section{$H_{3}$ : Gold Price has a negative effect on the LQ45 Index on the Indonesia Stock Exchange 2012 - 2018.}

Based on the results of the analysis, it is found that the Dow Jones Index has a positive effect on the LQ45 Index on the Indonesia Stock Exchange 2012 - 2018 amounting to 0.018364 with a significance level smaller than 0.05 , it is concluded 
that the effect is significant. From the analysis, it can be seen that the effect of the Dow Jones Index is following the hypothesis where the effect is significant. This happens because until now the American economy has become a reference for economies in other countries in the world, especially Indonesia, so that changes or developments that occur in the American economy, especially on the Dow Jones Index, will either directly or indirectly impact the economy in Indonesia in particular. LQ45 Index. Research that supports these results is research conducted by (Nezky, 2013), (Fuadi, 2013), (Virby, 2013).

\section{H4: The Dow Jones Index has a positive effect on the LQ45 Index on the Indonesia Stock Exchange 2012 - 2018.}

Based on the results of the analysis, it is found that the AEX Index has a positive effect on the LQ45 Index on the Indonesia Stock Exchange 2012 - 2018 amounting to 0.235421 with a significance level less than 0.05 , it is concluded that the effect is significant. From the analysis results, it can be seen that the effect of the AEX Index is by the hypothesis where the effect is significant. This occurs because the Netherlands is one of the largest export destinations in the European region, so the improvement in the Dutch economy as reflected in the AEX Index can boost the value of Indonesia's exports to the Netherlands. By increasing the value of Indonesia's exports to the Netherlands, it can indirectly increase the LQ45 Index.

\section{H5: The AEX Index has a positive effect on the LQ45 Index on the Indonesia Stock Exchange 2012 - 2018.}

Based on the results of the analysis, it is found that the DAX Index has a positive effect on the LQ45 Index on the Indonesia Stock Exchange 2012 - 2018 amounting to 0.024338 with a significance level smaller than 0.05 , it is concluded that the effect is significant. From the results of the analysis, it can be seen that the effect of the DAX Index is by the hypothesis where the effect is significant. This is because the economic relationship between Germany and Indonesia during the observation period has always increased, both in terms of Indonesian exports to Germany and from the perspective of German investment in Indonesia. Research that supports these results is research conducted by (Fuadi, 2013), (Tarigan, 2015), (Sawitri \& Astuty, 2018).

\section{H6: The DAX Index has a positive effect on the LQ45 Index on the Indonesia Stock Exchange 2012 - 2018.}

Based on the results of the analysis, it is found that the Shanghai Index has a positive effect on the LQ45 Index on the Indonesia Stock Exchange 2012 - 2018 amounting to 0.022803 with a significance level greater than 0.05 , it is concluded that the effect is not significant. From the analysis results, it can be seen that the effect of the Shanghai Index is not by the hypothesis where the effect is not significant. Until now, the Shanghai Index tends to be protected or in other words more closed, where foreign investors are not able to do much stock exchange activity on the Chinese capital market. Investors are more likely to make 
investment transactions through Hong Kong. With its closed nature, the China Stock Exchange (Shanghai Index) has minimal influence on world bourses, especially the Jakarta Stock Exchange (especially the LQ45 Index).

Besides, there was turmoil in the Chinese capital market in 2017 where the increase in the Shanghai Index was considered unnatural, requiring the Chinese Government to intervene in handling the turmoil that occurred so that the share value returned to fair trading. Several policies have been taken by the Chinese Government to reduce turmoil in the capital market. Due to these events, investors temporarily stopped using the Shanghai Index as a reference. Research that supports these results is research conducted by (Marjohan, 2015), (Yulianti \& Purwohandoko, 2019), (Batai et al., 2017).

\section{H7: The Shanghai Index has a positive effect on the LQ45 Index on the Indonesia Stock Exchange 2012 - 2018.}

\section{E. CONCLUSIONS}

During the observation period, interest rates did not experience significant fluctuations so that the interest rate variable was not a consideration for investors in investing. So it is hoped that Bank Indonesia can reduce the benchmark interest rate (BI Rate) to increase the Indonesian economy. Besides, the high exchange rate of the rupiah against the dollar also has an impact on the prices of imported goods and will also suppress exports, therefore an effort to maintain stability is to maintain domestic foreign exchange needs. As an investment instrument with relatively small risk, with relatively small profits, gold can be considered as an alternative to investing as an emergency reserve fund, so that at any time, companies/investors need funds quickly, it can be obtained through gold investment.

The fluctuation of the LQ45 movement is influenced by the Dow Jones Index (United States American Index), AEX (Dutch Index), and DAX (German Index) in a positive and significant direction. This is because until now the United States economy has become a reference for economies in other countries in the world, especially Indonesia, so that changes or developments that occur in the United States economy, especially on the Dow Jones Index, will either directly or indirectly impact the economy in Indonesia. particularly the LQ45 Index. The AEX and DAX indexes also have a positive impact on the Indonesian economy because the relationship between the two countries is closely related to exports and investments that have been established together. Meanwhile, the Shanghai Index tends to be protected, investors tend to make investment transactions through Hong Kong. Besides, there was turmoil in the Chinese capital market in 2017 where the increase in the Shanghai Index was deemed unnatural, thus requiring the Chinese Government to intervene in handling the turmoil that occurred. As a result, the Shanghai Index was not used as a reference by investors. 


\section{REFERENCES}

Aditya, Bonar M. Sinaga \& TB. Ahmad Maulana. 2018. Pengaruh Indeks Bursa Luar Negeri, Indikator Makroekonomi dan Krisis Ekonomi Global Terhadap Indeks Harga Saham Gabungan di Indonesia. Jurnal Aplikasi Manajemen dan Bisnis, Vol 4, No 2. Mei 2018.

Widyasa, Ananda, Vitra Islami \& Saparila Worokinasih. 2018. Pengaruh Tingkat Inflasi, Nilai Tukar Rupiah dan Tingkat Suku Bunga Domestik Terhadap Indeks Saham Syariah Indonesia (ISSI). Jurnal Administrasi Bisnis (JAB), Vol 60 No $1: 119$ - 128. Juli 2018.

Batai, Alimaa, Amanda M.Y. Chu, Zhihui Lv, \& Wing-Keung Wong. 2017. China's Impact on Mongolian Exchange Rate. Journal of Management Information and Decision Sciences, Vol 20, Special Issues 1532-5806-20SI-105. 2017.

Chabacib, H.M. \& Ardian A, Witjaksono, 2011. Analisis Pengaruh Fundamental Makro dan Indeks Harga Global terhadap IHSG. Karisma, 5 (4): 6372.

Deltiana, Tita \& Stella. 2009. Pengaruh Indeks Dow Jones, Nikkei 225, KOSPI, dan Shanghai Composite Index Terhadap Indeks Harga Saham Gabungan Bursa Efek Indonesia Periode Tahun 2004 -2008. Journal The WINNERS, Vol 10, No 1, Maret 2009.

Desfiandi, Andi, Alvin Desfiandi \& Hapzi Ali. 2017. Composite Stock Price Index (IHSG) Macro Factor in Investment in Stock (Equity Funds). International Journal of Economics and Financial Issues, Vol 7, Issues 3, ISSN: 2146-4138. 2017.

Haider, Syed Mujahat. 2018. Impact of Interest Rate, Inflation Rate, Exchange Rate, and Gold Prices on Karachi Meezan Index 30. European Journal of Islamic Finance (EJIF), No. 10, ISSN 2421-2172. August 2018.

Husnul, Habib Muhammad, Raden Rustam Hidayat \& Sri Sulasmiyati. 2017. Analisis Pengaruh Inflasi, Kurs (IDR/USD), Produk Domestik Bruto dan Harga Emas Dunia terhadap Indeks Harga Saham Gabungan (Studi Pada Indonesia Periode 2008 - 2016). Jurnal Administrasi Bisnis, Vol 53 No 1 : 66 - 74. Desember 2017.

Ilmi, Maisaroh Fathul. 2017. Pengaruh Kurs/Nilai Tukar Rupiah, inflasi dan Tingkat Suku Bunga SBI Terhadap Indeks Harga Saham Gabungan LQ45 Periode Tahun 2009 - 2013. Jurnal Nominal, Vol IV No 1 : 95 - 108. 2017.

Kusumawati, Dyah Ayu \& Nadia Asandimitra. 2017. Impact of Global Index, Gold Price, and Macro-Economic Variable for Indonesia Composite Index. Research Journal of Finance and Accounting, Vol 8, No 2, ISSN 22222847.2017.

Marjohan, Masno. 2015. Effect of Stock Price Index in Global Stock against Composite Stock Price Index (CSPI) Study on the Indonesia Stock 
Exchange. IOSR Journal of Economics and Finance (IOSR-JEF), Vol 6, Issue 2. Ver III, e-ISSN: 2321-5933, p-ISSN: 2321-5925. April 2015.

Nezky, Mita. 2013. The Impact of US Crisis on Trade and Stock Market in Indonesia. Bulletin of Monetary, Economics, and Banking. January 2013.

Fuadi, Ilham \& Andini Nurwulandari 2013. Pengaruh Keseimbangan Jangka Panjang dan Jangka Pendek Indeks DJIA, FTSE 100, DAX 30, CAC 40, dan Nikkei 225 Terhadap Indeks Harga Saham Gabungan (IHSG). Jurnal Imliah Akuntansi dan Bisnis, Vol 8 No 1. Januari 2013.

Purnamawati, I Gusti Ayu \& Desak Nyoman Sri Werastuti. 2013. Faktor Fundamental Ekonomi Makro terhadap Harga Saham LQ45. Jurnal Keuangan dan Perbankan, Vol 17 No $2: 211$ - 219. Mei 2013.

Robiyanto. 2018. The Effect Of Gold Price Changes, USD/IDR Exchange Rate Changes, And Bank Indonesia (BI) Rate On Jakarta Composite Index (JCI)'s Return And Jakarta Islamic Index (JII)'s Return. JMK, Vol 20, No 1, ISSN 2338-8234. March 2018.

Sakinah. 2016. Globalisasi Makro Ekonomi terhadap Pasar Modal Indonesia. Jurnal Eksis, Vol 7 No 2 : 99 - 116. November 2016.

Santosa, Perdana Wahyu \& Nita Puspitasari. 2019. Corporate Fundamentals, BI Rate And Systematic Risk: Evidence From Indonesia Stock Exchange. Jurnal Manajemen, Vol. XXIII, No. 01. 1 February 2019.

Sawitri, N.N. \& P. Astuty. 2018. Market Anomalies and Effect on Returns. European Research Studies Journal, Vo. XXI, Issue 2. 2018.

Surbakti, Emta Hariati, Noer Azam Achsani \& Tubagus Nur Ahmad Maulana. 2016. The Impact of Macroeconomic Variables on JCI's Stock Return Volatility in Pre and Post Global Economic Crisis. International Journal of Scientific and Research Publications, Vol. 6, Issue 3. March 2016.

Syarif, Moh Maulidi \& Nadia Asandimitra. 2015. Pengaruh Indikator Makro Ekonomi Dan Faktor Global Terhadap Indeks Harga Saham Gabungan (IHSG). Journal of Management Studies, Vo. 9, No. 2. 17 Mei 2015.

Tarigan, Razaq Dastanta, Suhadak \& Topowijono. 2015. Pengaruh Indeks Harga Saham Global Terhadap Indeks Harga Saham Gabungan (IHSG) Studi Pada Bursa Efek Indonesia (BEI) Periode 2011-2014. Jurnal Administrasi Bisnis (JAB), Vol 24, No 1. Juli 2015.

Tjandrasa, Benny Budiawan \& Rosemarie Sutjiati. 2016. Effect of World Gold Price, Crude Oil Price and Interest Rate to Jakarta Composite Index. International Journal of Education and Research, Vol 4, No 7. July 2016.

Virby, Shelby. 2018. Pengaruh Indeks Dow Jones Industrial Average,Nikkei 225, Hangseng Index, dan Shanghai Stock Exchange Terhadap Indeks Harga Saham Gabunga Bursa Efek Indonesia Periode Tahun 2008-2013. Inovasi Jurnal Ilmiah Ilmu Manajemen, Vol 5, No 2. 2018. 
Wahyudi, Sugeng, H. Hersugondo, Rio Dhani Lhaksana \& R. Rudy. 2017. Macroeconomic Fundamental and Stock Price Index in Southeast Asia Countries: A Comparative Study. International Journal of Economics and Financial Issues, Vol 7, No 2, ISSN: 2146-4138. 2017.

Widyasa, Ananda, Vitra Islami \& Saparila Worokinasih. 2018. Pengaruh Tingkat Inflasi, Nilai Tukar Rupiah dan Tingkat Suku Bunga Domestik Terhadap Indeks Saham Syariah Indonesia (ISSI). Jurnal Administrasi Bisnis (JAB), Vol 60 No $1: 119$ - 128. Juli 2018.

Lai, Yeen Khong, Lee Sin Yee, Mahendra Kumar \& Chelliah. 2017. Relationship Between Macroeconomic and Stock Market: Empirical Study in Malaysia. Journal of Research in Business, Economics, and Management (JRBEM), Vol 8, Issue 1, ISSN: 2395-2210. January 2017.

Yulianti, Melinda Tety \& Purwohandoko. 2019. Pengaruh Variabel Makroekonomi, Harga Komoditas \& Indeks Saham Global Terhadap IHSG Periode 2014-2018. Jurnal Ilmu Manajemen, Vol. 7, No. 3. 2019. 